\title{
Phenolic and Tyrosyl Ring Deiodination of Iodothyronines in Rat Brain Homogenates
}

\author{
Michael M. Kaplan and Kimberlee A. Yaskoski, Thyroid Unit, \\ Peter Bent Brigham Hospital Division of Affiliated Hospitals Center, and \\ Harvard Medical School, Boston, Massachusetts 02115
}

A B S T RA C T Conversion of thyroxine $\left(\mathrm{T}_{4}\right)$ to $3,5,3^{\prime}$ triiodothyronine $\left(\mathrm{T}_{3}\right)$ in rat brain has recently been shown in in vivo studies. This process contributes a substantial fraction of endogenous nuclear $T_{3}$ in the rat cerebral cortex and cerebellum. Production of $\mathrm{T}_{4} \mathrm{me}-$ tabolites besides $T_{3}$ in the brain has also been suggested. To determine the nature of these reactions, we studied metabolism of $\left.0.2-1.0 \mathrm{nM}^{[25}{ }^{12}\right] \mathrm{T}_{4}$ and $0.1-$ $0.3 \mathrm{nM}\left[{ }^{131} \mathrm{I}\right] \mathrm{T}_{3}$ in whole homogenates and subcellular fractions of rat cerebral cortex and cerebellum. Dithiothreitol (DTT) was required for detectable metabolic reactions: $100 \mathrm{mM}$ DTT was routinely used. Ethanol extracts of incubation mixtures were analyzed by paper chromatography in t-amyl alcohol:hexane: ammonia and in 1-butanol:acetic acid. Rates of production of iodothyronines from $\mathrm{T}_{4}$ and $\mathrm{T}_{3}$ were greater at pH 7.5 than at 6.4 or 8.6 and greater at $37^{\circ} \mathrm{C}$ than at $22^{\circ}$ or $4^{\circ} \mathrm{C}$. Lowering the $\mathrm{pH}$, reducing the protein or DTT concentrations, and preheating homogenates to $100^{\circ} \mathrm{C}$ all increased excess $\mathrm{I}^{-}$production but reduced iodothyronine production.

In cerebral cortical homogenates from normal rats, products of $\mathrm{T}_{4}$ degradation were as follows (percent added $\mathrm{T}_{4} \pm \mathrm{SEM}$ in nine experiments): $\mathrm{T}_{3}, 1.9 \pm 0.5 \%$; $3,3^{\prime}, 5^{\prime}$-triiodothyronine $\left(\mathrm{rT}_{3}\right), 34.0 \pm 2.4 \% ; 3,3^{\prime}$-diiodothyronine $\left(3,3^{\prime}-\mathrm{T}_{2}\right), 5.8 \pm 1.6 \% ; 3^{\prime}$-iodothyronine $\left(3^{\prime}-\mathrm{T}_{1}\right)$, $\leq 2.5 \%$; and excess $\mathrm{I}^{-}, 4.7 \pm 1.2 \%$. In the same experiments, products of $\mathrm{T}_{3}$ degradation were $3,3^{\prime}-\mathrm{T}_{2}, 63.3$ $\pm 5.5 \%$, and $3^{\prime}-\mathrm{T}_{1}, 12.6 \pm 1.4 \%$. Cerebral cortical homogenates from hyperthyroid rats and normals were similar in regard to $T_{4}$ to $T_{3}$ deiodination. In contrast, in cerebral cortical homogenates from hypothyroid rats, phenolic ring deiodination rates were increased and tyrosyl ring

A portion of this work was presented at the Annual Meeting of the American Federation for Clinical Research, May 1980, Washington, D. C., and appeared in abstract form in Clin. Res. 28: 262A.

Received for publication 22 January 1980 and in revised form 21 April 1980. deiodination rates were decreased compared with normals.

$T_{4}$ to $T_{3}$ conversion rates in cerebellar homogenates were greater than rates in cerebral cortical homogenates from the same normal rats and less than rates in cerebellar homogenates from hypothyroid rats. $\mathrm{T}_{4}$ and $\mathrm{T}_{3}$ tyrosyl ring deiodination rates were greatly diminished in cerebellar homogenates compared with cerebral cortical homogenates in normal and hypothyroid rats. High-speed $(1,000-160,000 \mathrm{~g})$ pellets from cerebral cortical homogenates were enriched in phenolic and tyrosyl ring deiodinating activities relative to cytosol. Fractional conversion of $T_{4}$ to $T_{3}$ was inhibited by $\mathrm{T}_{4}$, iopanoic acid, and $\mathrm{rT}_{3}$, but not by $\mathrm{T}_{3}$. Tyrosyl ring deiodination reactions were inhibited by $\mathrm{T}_{3}, \mathrm{~T}_{4}$, and iopanoic acid, but not by $\mathrm{rT}_{3}$.

These studies demonstrate separate phenolic and tyrosyl ring iodothyronine deiodinase enzymes in rat brain. The brain phenolic ring deiodinase serves in vivo as a $\mathrm{T}_{4} 5^{\prime}$-deiodinase and closely resembles anterior pituitary $\mathrm{T}_{4} 5^{\prime}$-deiodinase in physiological and biochemical characteristics. The physiological significance of the tyrosyl ring iodothyronine deiodinase enzyme is unclear; it shares several properties with rat hepatic $\mathrm{T}_{4} 5$-deiodinase.

\section{INTRODUCTION}

In clinical medicine, the brain is clearly responsive to excessive and deficient supplies of thyroid hormones. Congenital hypothyroidism is accompanied by morphological abnormalities of the cerebral cortex and cerebellum and by corresponding derangements of central nervous system function in man and other species (1-5) (see [1-4] for recent reviews). Both hyperthyroidism and hypothyroidism cause abnormalities of cognitive function in adult patients $(6,7)$. The molecular events necessary for the expression of thyroid hormone effects on the brain remain poorly understood. Schwartz and Oppenheimer $(8,9)$ identified nuclear 
3,5,3'-triiodothyronine $\left(\mathrm{T}_{3}\right)^{1}$ binding sites in rat brain cells with physical properties similar to those of nuclear $T_{3}$ receptors in other rat tissues. They found differences in the maximal nuclear $T_{3}$ binding capacity in different areas of the brain (9), and they and others have described changes in cortical and cerebellar nuclear $T_{3}$ binding with age in newborn rats $(10,11)$. Dratman et al. (12) found localization of $\left[{ }^{125} \mathrm{I}\right] \mathrm{T}_{3}$ within synaptosomal vesicles from whole rat cerebral hemispheres after in vivo injection of $\left[{ }^{125} \mathrm{I}\right] \mathrm{T}_{3}$. Dozin-Van Roye and DeNayer (13) demonstrated saturable binding of $T_{3}$ to brain cytosol proteins in vitro. The physiological significance of these observations is not yet known.

There is evidence for metabolism of thyroid hormones in brain tissue in vivo. Dratman and Crutchfield (14) injected $\left[{ }^{125} \mathrm{I}\right]$-thyroxine $\left(\left[{ }^{125} \mathrm{I}\right] \mathrm{T}_{4}\right)$ to thyroidectomized rats given $T_{4}$ replacement. In brain homogenates they found $T_{3}$, which was most abundant in the synaptosome fraction, and small quantities of two other compounds, one identified as 3,3',5'-triiodothyronine $\left(\mathrm{rT}_{3}\right)$ and the other as a common metabolite of $\mathrm{T}_{4}$ and $\mathrm{T}_{3}$. Vigouroux et al. (15) identified $\left[{ }^{125} \mathrm{I}\right] \mathrm{T}_{3}$ in extracts of rat brain after in vivo administration of $\left[{ }^{125} \mathrm{I}\right] \mathrm{T}_{4}$. Obregon et al. (16) administered $\left[{ }^{131} \mathrm{I}\right] \mathrm{T}_{4}$ and $\left.{ }^{[25} \mathrm{I}\right] \mathrm{T}_{3}$ simultaneously, and found that brain tissue had a higher $\left[{ }^{131} \mathrm{I}\right] \mathrm{T}_{3}:\left[{ }^{125} \mathrm{I}\right] \mathrm{T}_{3}$ ratio than liver, kidney, heart, and skeletal muscle, suggesting local production in brain. Crantz and Larsen (17) injected normal rats with $\left[{ }^{125} \mathrm{I}^{1} \mathrm{~T}_{4}\right.$ and $\left.{ }^{[131}{ }^{1}\right] \mathrm{T}_{3}$ in vivo and isolated cell nuclei from the cerebral cortex and cerebellum. They found that a substantial fraction of nuclear $T_{3}$ in these regions was produced locally and that in vivo iopanoic acid treatment abolished the appearance of locally produced nuclear $\mathrm{T}_{3}$.

In vitro studies of metabolism of thyroid hormones in brain tissue have also been reported. Tata et al. (18) found degradation of $\left.{ }^{[131} \mathrm{I}\right] \mathrm{T}_{4}$ and $\left.{ }^{\left[{ }^{131}\right.} \mathrm{I}\right] \mathrm{T}_{3}$ in brain homogenates of chickens and dogs. They tentatively identified tetraiodothyroacetic acid and triiodothyroacetic acid, or the analogous propionic acid derivatives, as minor products. They also found that small amounts of degraded $\mathrm{T}_{4}$ sometimes appeared as $\mathrm{T}_{3}$, but iodide constituted the great bulk of the identifiable $\mathrm{T}_{4}$ degradation products in their studies. We $(19,20)$ and Chopra (21) previously tested brain tissue for $\mathrm{T}_{4}$ 5 '-deiodinase activity but found little or no change in radioimmunoassayable $T_{3}$ in ethanolic extracts of the homogenates. In these experiments, it is possible that significant $T_{4}$ to $T_{3}$ conversion occurred in brain homogenates at rates lower than those found in homog-

\footnotetext{
'Abbreviations used in this paper: BAA, 1-butanol:acetic acid:water::78:5: 17; DTT, dithiothreitol; TAA, t-amyl alcohol: hexane: $2 \mathrm{~N}$ ammonia::5:1:6 (upper phase); $\mathrm{T}_{4}$, thyroxine; $\mathrm{T}_{3}$, 3,5,3'-triiodothyronine; $\mathrm{rT}_{3}, 3,3^{\prime}, 5^{\prime}$-triiodothyronine; $3,3^{\prime}-\mathrm{T}_{2}$, $3,3^{\prime}$-diiodothyronine; $3^{\prime}, 5^{\prime}-\mathrm{T}_{2}, 3^{\prime}, 5^{\prime}$-diiodothyronine; $3^{\prime}-\mathrm{T}_{1}$, 3 '-iodothyronine.
}

enates of other tissues (19-21), but was difficult to detect against the background of $T_{3}$ contaminating the large quantities of $\mathrm{T}_{4}$ used.

To establish the biochemical characteristics of $T_{4} 5^{\prime}$ deiodination in brain, we have reexamined $\mathrm{T}_{4}$ metabolism in vitro, using a sensitive radiometric technique for identification and quantitation of reaction products. We investigated the effects of hypothyroidism and hyperthyroidism, since both of these conditions stimulate $\mathrm{T}_{4} 5^{\prime}$-deiodinase activity in some tissues $(20,22,23)$. Initial experiments disclosed several degradation products of $T_{4}$ besides $T_{3}$ in brain homogenates. We have attempted to identify those substances and characterize the factors that influence their production.

\section{METHODS}

Animals and reagents. Adult male Sprague-Dawley rats (Zivic Miller Laboratories, Allison Park, Pa.) were used in all experiments. Hypothyroid rats were supplied thyroidectomized with parathyroid implants. Hypothyroidism was judged by a weight gain of $<100 \mathrm{~g}$ in $60 \mathrm{~d}$ after surgery; intact rats of the same age gain $210-300 \mathrm{~g}$ in $56 \mathrm{~d}$ (data from supplier). Rats meeting this criterion have had uniformly low serum $T_{4}$ and high serum thyrotropin concentration in past studies (24), although serum hormone levels were not routinely measured in the present studies. In one experiment, normal rats were made hyperthyroid by injection of $T_{4}, 10$ $\mu \mathrm{g} / 100 \mathrm{~g}$ body wt s.c. daily for $5 \mathrm{~d}$ and sacrificed $24 \mathrm{~h}$ after the last injection. In this experiment, the mean $( \pm$ SD) serum levels for the normal and hypothyroid rats (both vehicle injected) and the hyperthyroid rats were as follows: $\mathrm{T}_{4}, 4.8 \pm 0.4$, $1.3 \pm 1.0$, and $13.3 \pm 1.9 \mu \mathrm{g} / \mathrm{dl}$; thyrotropin, $190 \pm 30,864 \pm 365$, and $30 \pm 10 \mu \mathrm{U} / \mathrm{ml}$.

Levorotatory iodothyronines were used exclusively. $\left[{ }^{125} \mathrm{I}\right] \mathrm{T}_{4}$ was purchased from New England Nuclear, Boston, Mass., or synthesized in our laboratory by the method of Weeke and Orskov (25). $\left[{ }^{131} I\right] \mathrm{T}_{3}$ and $\left[{ }^{131} \mathrm{I}\right] \mathrm{rT}_{3}$ were synthesized in our laboratory by the same method. Tracers contained $<10 \% \mathrm{I}^{-}$. Nonradioactive iodothyronines were obtained from Henning Gmbh, Berlin, and the Sigma Chemical Co., St. Louis, Mo. Iopanoic acid (Telepaque ${ }^{\mathrm{R}}, 3$-[3-amino-2,4,6-triiodophenyl]2 ethylpropionic acid) was generously donated by Mr. A. E. Soria, Sterling-Winthrop Research Institute, Renssalaer, N. Y. Other reagents and solvents were purchased from Fisher Scientific Co., Pittsburgh, Pa. and Sigma Chemical Co.

Preparation of homogenates. Rats were decapitated under ether anesthesia and the brains removed. Pieces of cerebral cortex, free of white matter, and the whole cerebellums were dissected with a fine scissors, weighed, and homogenized as described (20) in 9 vol ice-cold $0.05 \mathrm{M}$ Tris, pH 7.6-0.25 M sucrose- $100 \mathrm{mM}$ dithiothreitol (DTT). The $\mathrm{pH}$ of the homogenates was 7.5 at $37^{\circ} \mathrm{C}$. Unless noted, tissues from three rats were pooled to make the homogenates. In experiments testing the effects of thiol concentrations, tissues were homogenized in $8 \mathrm{ml} / \mathrm{g}$ Tris-sucrose without DTT; then $1 \mathrm{ml} / \mathrm{g}$ tissue of various DTT or GSH solutions was added to homogenate aliquots. In fractionation studies, homogenates were centrifuged at $1,000 \mathrm{~g}$, and the resulting supernate was centrifuged for 45 min at $38,000 \mathrm{rpm}$ in a Beckman model L centrifuge (Beckman Instruments, Fullerton, Calif.) with an SW 501 rotor. The low- and high-speed pellets were resuspended to the original volume in Tris-sucrose-100 $\mathrm{mM}$ DTT as described (20). The high-speed pellet was centrifuged again at 38,000 
rpm for $\mathbf{4 5} \mathrm{min}$ and finally suspended to the original volume in Tris-sucrose-100 $\mathrm{mM}$ DTT.

Incubation procedure. Incubations were carried out under $\mathrm{N}_{2}$ at $37^{\circ} \mathrm{C}$ as detailed previously (20). $90 \mu \mathrm{l}$ of homogenate or Tris-sucrose-DTT solution was mixed with $10 \mu \mathrm{l}$ of substrate solution to start the reactions. $10 \mu$ l of the substrate solution contained $\sim 40,000 \mathrm{cpm}\left[{ }^{125} \mathrm{I}\right] \mathrm{T}_{4}(1,100-2,500 \mu \mathrm{Ci} / \mu \mathrm{g})$ and $6,000-20,000 \mathrm{cpm}\left[{ }^{131} \mathrm{I}\right] \mathrm{T}_{3}(\sim 3000 \mu \mathrm{Ci} / \mu \mathrm{g})$, equal to $0.2-1.0$ $n M T_{4}$ and $0.1-0.3 \mathrm{nM} \mathrm{T}_{3}$ (these and all other concentrations are given as concentrations in the incubation mixture at the start of the incubations). $T_{4}$ and $T_{3}$ concentrations in these ranges were far below satuarating concentrations, so that fractional degradation rates were not concentration dependent and data from different experiments could be compared. Other compounds were added to tracer solutions before the tracers were added to homogenates. Incubations were stopped by addition of $200 \mu$ l ethanol plus $50 \mu l 0.04 \mathrm{~N} \mathrm{NaOH}$ containing $50 \mu \mathrm{g} \mathrm{T}_{4}, 50 \mu \mathrm{g} \mathrm{T}_{3}$, and $285 \mu \mathrm{g}$ methimazole. The tubes were then centrifuged, yielding a pellet $\sim 25 \mu$ l volume. $89-97 \%$ of both tracer $T_{4}$ and tracer $T_{3}$ were recovered into the ethanolic supernate.

Analytical methods. 75-125 $\mu$ l of the ethanolic extracts was mixed with carrier $\mathrm{T}_{4}, \mathrm{~T}_{3}$, and $\mathrm{NaI}$, and subjected to descending paper chromatography using the t-amyl alcohol:hexane:2 $\mathrm{N}$ ammonia::5:1:6 (TAA) system of Bellarbarba et al. (26). Carriers were identified by spraying with color reagents. ${ }^{2}$ In some experiments, various peaks of radioactivity were eluted from unsprayed chromatograms with methanol:ammonia (99:1). These were concentrated under a stream of nitrogen, mixed with carrier compounds, and chromatographed again either in the TAA system or in a descending paper system of 1-butanol:acetic acid:water (78:5:17) (BAA) (27).

In experiments designed to identify reaction products, chromatograms were cut into $1-\mathrm{cm}$ segments. In subsequent experiments, TAA chromatograms were cut into 10 segments. The $\mathrm{I}^{-}, \mathrm{T}_{4}$, and $\mathrm{T}_{3}$ carrier spots were in segments 2,5 , and 9 , respectively. Segments $1-9$ were $\sim 2.5 \mathrm{~cm}$ in length, while segment 10 was between $T_{3}$ and the front. Changes in ${ }^{125} I$ and ${ }^{131} I$ in segments $6-8$ were attributed to 3,3'-diiodothyronine $\left(3,3^{\prime}-\mathrm{T}_{2}\right)$, changes in ${ }^{125} \mathrm{I}$ in segments 3 and 4 were attributed to $\mathrm{rT}_{3}$ and changes in ${ }^{131} \mathrm{I}$ in segments 4 and 5 were attributed to $3^{\prime}$-iodothyronine $\left(3^{\prime}-\mathrm{T}_{1}\right)$ (see Results).

Phenolic ring monodeiodination of $\left[{ }^{125} \mathrm{I}^{2} \mathrm{~T}_{4}\right.$ or $\left[{ }^{125} \mathrm{I}\right] \mathrm{rT}_{3}$ will produce equimolar amounts of ${ }^{125} \mathrm{I}^{-}$and $\left[{ }^{125} I\right] \mathrm{T}_{3}$, or $\left[{ }^{125} I\right] 3,3^{\prime}-\mathrm{T}_{2}$, respectively. This is true whether one or two ${ }^{125} \mathrm{I}$ atoms are present on the phenolic ring of $\mathrm{T}_{4}$ or $\mathrm{rT}_{3}$. [ $\left.{ }^{125} \mathrm{I}\right] 3,3^{\prime}-\mathrm{T}_{2}$ and [125I] $3^{\prime}-\mathrm{T}_{1}$, produced from newly generated $\left[{ }^{125} \mathrm{I}\right] \mathrm{T}_{3}$, will also be matched by equal amounts of ${ }^{125} \mathrm{I}^{-}$produced along with the intermediate $\left[{ }^{125} \mathrm{I}\right] \mathrm{T}_{3} .{ }^{125} \mathrm{I}^{-}$appearing in excess of $\left[{ }^{125} \mathrm{I}\right] \mathrm{T}_{3}$ plus $\left.{ }^{[25} \mathrm{I}\right] 3,3^{\prime}-\mathrm{T}_{2}$ is designated excess $\mathrm{I}^{-}$. Excess $\mathrm{I}^{-}$includes $\mathrm{I}^{-}$corresponding to $\left[{ }^{125} \mathrm{I}\right] 3^{\prime}-\mathrm{T}_{1}$ production (since that compound was not routinely separable from $\left[{ }^{125} \mathrm{I}\right] \mathrm{T}_{4}$ or $\left[{ }^{125} \mathrm{I}\right] \mathrm{rT}_{3}$ ), $\mathrm{I}^{-}$produced by phenolic ring deiodination of $\left[3,3^{\prime}\right] \mathrm{T}_{2}$ and $3^{\prime}-\mathrm{T}_{1}, \mathrm{I}^{-}$produced by the process observed in the boiled homogenates (see Results) and $3^{\prime}, 5^{\prime}$-diiodothyronine $\left(3^{\prime}, 5^{\prime}-\mathrm{T}_{2}\right)$, which cochromatographs with iodine (28).

${ }^{2}$ An Appendix has been deposited with the National Auxiliary Publication Service (NAPS) as NAPS document 03696. This information may be ordered from ASIS/NAPS, Microfiche Publications, P. O. Box 3513, Grand Central Station, New York 10017. Remit in advance, in U. S. funds, $\$ 3.00$ for microfiche copy or for photocopy, $\$ 5.00$ up to 20 pages plus 25 for additional pages. Outside the U.S. and Canada add postage of $\$ 3.00$ for photocopy and $\$ 1.00$ for microfiche. Checks should be made payable to Microfiche Publications.
Paper electrophoresis employed a Durrum-type cell (Beckman Instruments, Inc.) in $0.3 \mathrm{M}$ glycine- $0.15 \mathrm{M}$ acetate buffer, pH 8.6. Protein was measured in triplicate by the method of Lowry et al. (29). Since DTT strongly interferes in the protein assay, homogenate aliquots and bovine serum albumin standards were precipitated with $5 \mathrm{ml} 7 \%$ perchloric acid, pelleted, washed with the same amount of perchloric acid, pelleted again, and dissolved in $0.1 \mathrm{~N} \mathrm{NaOH}$.

Calculations. Each experiment included extracts of Trissucrose-100 $\mathrm{mM}$ DTT made immediately after addition of tracer (zero time) and incubations with Tris-sucrose-100 mM DTT for $2 \mathrm{~h}$. The percent radioactivity in each segment of the chromatograms from the $2 \mathrm{~h}$ incubations with Tris-sucrose$100 \mathrm{mM}$ DTT was subtracted from the percent radioactivity in the corresponding segments from incubations containing brain tissue. This figure for each chromatogram segment was divided by the percent radioactivity in the zero-time $\left[{ }^{125} \mathrm{I}\right] \mathrm{T}_{4}$ or $\left[{ }^{131} \mathrm{I}\right] \mathrm{T}_{3}$ spots, as appropriate, to yield the fraction of added $T_{4}$ or $T_{3}$ degraded or the fractions of added $T_{4}$ to $T_{3}$ converted by the tissue to the various reaction products. Measured quantities of $5^{\prime}$-deiodination products of $\mathrm{T}_{4}$ were doubled to correct for simultaneous ${ }^{125} \mathrm{I}^{-}$production. Statistical comparisons were made using the $t$ test for paired or unpaired values as appropriate, and by two-way analysis of variance, using the statistical package of Hewlett-Packard 9815A programmable calculator (Hewlett-Packard Co., Palo Alto, Calif.).

\section{RESULTS}

Characterization of reaction products. The distributions of radioactivity on chromatograms of zerotime extracts of cerebral cortical homogenates and of Tris-sucrose-100 $\mathrm{mM}$ DTT were indistinguishable from the distribution of radioactivity of chromatograms of original tracer solutions. In these chromatograms, peaks of ${ }^{125} \mathrm{I}$ radioactivity were found only in the $\mathrm{I}^{-}$and $\mathrm{T}_{4}$ carrier spots, and peaks of ${ }^{131} \mathrm{I}$ radioactivity were found only in the $\mathrm{I}^{-}$and $\mathrm{T}_{3}$ carrier spots. There was no evidence of formation, during extraction or thereafter, of $T_{4}$ or $T_{3}$ esters or of complexes of $T_{4}$ to $T_{3}$ with ethanol-soluble lipids. After $2-\mathrm{h}$ incubations with Trissucrose, with Tris-sucrose- $100 \mathrm{mM}$ DTT in the absence of tissue, or with whole cerebral cortical homogenates from normal or hypothyroid rats without DTT, the percent of total ${ }^{125} \mathrm{I}$ and ${ }^{131} \mathrm{I}$ radioactivity in the iodothyronine spots was $1-5 \%$ lower than that at zero time. Approximately half of this change was accounted for by an increase in radioactivity in the iodide spot, but the rest of the loss of starting material was not matched by the appearance of radioactivity in any other discrete area of the chromatograms. In particular, in these incubations, $<1 \%$ of added $\left[{ }^{125} \mathrm{I}_{\mathrm{T}} \mathrm{T}_{4}\right.$ radioactivity appeared in the $T_{3}$ spot after $2 \mathrm{~h}$.

Incubation of homogenates of cerebral cortical tissue from normal rats with $\left[{ }^{125} \mathrm{I}\right] \mathrm{T}_{4}$ and $\left[{ }^{131} \mathrm{I}\right] \mathrm{T}_{3}$ in the presence of $100 \mathrm{mM}$ DTT produced five reaction products (Fig. 1): $\left.{ }^{125} \mathrm{I}^{-} ;{ }^{125} \mathrm{I}\right] \mathrm{T}_{3} ;$ a $\mathrm{T}_{4}$ metabolite migrating in the TAA system between $\mathrm{I}^{-}$and $\mathrm{T}_{4}$ (compound $\mathrm{A}$ ); a $\mathrm{T}_{3}$ metabolite migrating in the TAA system slightly slower than $\mathrm{T}_{4}$ (compound B); and a common metabolite of $T_{4}$ and $T_{3}$ migrating in the TAA system midway between $\mathrm{T}_{4}$ and 


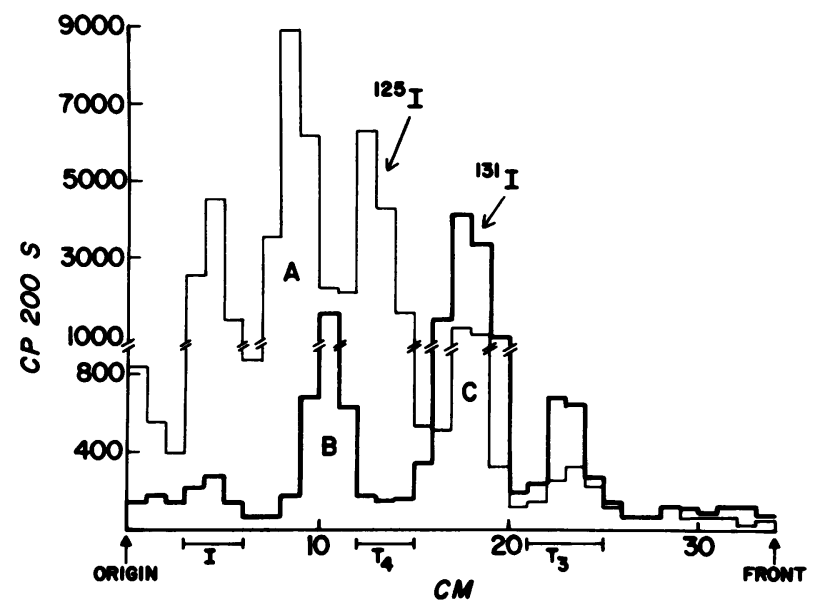

FIGURE 1 Representative TAA chromatogram of ethanolic extract of cerebral cortical homogenate from normal rats incubated for $2 \mathrm{~h}$ at $37^{\circ} \mathrm{C}$ with $0.9 \mathrm{nM}\left[{ }^{125} \mathrm{I}\right] \mathrm{T}_{4}, 0.1 \mathrm{nM}\left[{ }^{131} \mathrm{I}\right] \mathrm{T}_{3}$, and $100 \mathrm{mM}$ DTT. The thin line indicates ${ }^{125} \mathrm{I}$ radioactivity and the bold line indicates ${ }^{131} \mathrm{I}$ radioactivity in each $1-\mathrm{cm}$ chromatogram segment. There is no correction in this figure for radioactivity in the starting material. Lines under the abscissa indicate positions of the stained carrier $\mathrm{I}^{-}, \mathrm{T}_{4}$, and $T_{3}$ spots on this chromatogram.

$\mathrm{T}_{3}$ (compound $\mathrm{C}$ ). $\mathrm{I}^{-}$was always separated by at least $1.5 \mathrm{~cm}$ from the origin in the TAA system, and appearance of statistically significant quantities of radioactivity at the origin was not observed in the chromatograms. Percent recovery of total ${ }^{125}$ I and ${ }^{131} I$ radioactivity in the incubation mixtures into the liquid phase did not change over time: in a representative experiment, recovery of ${ }^{125} \mathrm{I}$ was $95 \pm 2$ and $97 \pm 3 \%$, and recovery of ${ }^{131} \mathrm{I}$ was $95 \pm 3$ and $96 \pm 1 \%$ at 0 and $2 \mathrm{~h}$, respectively. This observation excludes the formation in the incubation mixtures of subtantial amounts of ethanol-insoluble, proteinaceous, iodinated "origin material."

Compound A was eluted from several chromatograms, pooled, and rechromatographed in the BAA and TAA system. In both systems, compound $A$ radioactivity cochromatographed with $\mathrm{rT}_{3 .}{ }^{2}$ Compound $\mathrm{B}$ was eluted and rechromatographed with $\mathrm{T}_{4}$ standards and with 3'- $T_{1}$ standards. Compound $B$ was found to cochromatograph in both systems with $3^{\prime}-\mathrm{T}_{1}$. In the BAA system, compound $B$ was distinct from $T_{4}: R_{4}$ of $3^{\prime}-T_{1}$ and compound $B=0.73, R_{4}$ of $T_{4}=0.83$. Compound $C$ was eluted and rechromatographed in both systems with $3,3^{\prime}-T_{2}$ standards and with tetraiodothyroacetic acid standards. In both systems, all of the ${ }^{125} \mathrm{I}$ and ${ }^{131} \mathrm{I}$ radioactivity coincided with the $3,3^{\prime}-T_{2}$ standard. In the BAA system, tetraiodothyroacetic acid, $R_{\mathbf{q}}=0.92$, was completely distinct from $3,3^{\prime}-T_{2}, R_{4}=0.77$, and there was no radioactivity in the tetraiodothyroacetic acid spot above background. In some experiments, the formation of $3^{\prime}, 5^{\prime}-\mathrm{T}_{2}$ seemed possible. This compound is not separable from $\mathrm{I}^{-}$in the TAA system (28) and not separable from $\mathrm{T}_{4}$ in the BAA system (27); however, apparent $\mathrm{I}^{-}$production in individual samples could be compared in both systems. When this was carried out for incubation samples suspected of containing $3^{\prime}, 5^{\prime}-T_{2}$, there was no significant difference by which the presence of $3^{\prime}, 5^{\prime}-T_{2}$ could be inferred. There was never any radioactivity of TAA chromatograms compatable with the formation of triiodothyroacetic acid from $\mathrm{T}_{4}$ or $\mathrm{T}_{3}(27)$.

Effects of varying incubation $p H$, temperature, and time. When the $\mathrm{pH}$ of the incubations was adjusted to 6.4 or 8.6 , the $T_{4}$ to $T_{3}$ and $T_{3}$ to $3,3^{\prime}-T_{2}$ conversion rates were $<50 \%$ of the rates at $\mathrm{pH}$ 7.5. Likewise, there was a progressive decrease in the rates of these reactions when the temperature was lowered to $22^{\circ}$ and $4^{\circ} \mathrm{C}$. Heating the homogenates or high-speed pellets in a boiling water bath for $30 \mathrm{~min}$ abolished detectable production of any iodothyronines from $T_{4}$ or $T_{3}$. When whole cerebral cortical homogenates from normal and from hypothyroid rats were sampled every $30 \mathrm{~min}$ for $120 \mathrm{~min}$, plots of $\log$ (percent added $\mathrm{T}_{4}$ or $\mathrm{T}_{3}$ remaining) vs. time were linear. Thus, the fractional degradation rates of $T_{4}$ and $T_{3}$ were constant during this period. In the incubations with $\left.{ }^{131} I\right] T_{3}$, using normal tissue, substantial quantities of $\left[{ }^{131} \mathrm{I}\right] 3,3^{\prime}-\mathrm{T}_{2}$ appeared at $30 \mathrm{~min}$, before any detectable $\left[{ }^{131} I\right] 3^{\prime}-T_{1}$, and the ratio of $\left[{ }^{131} I\right]-$ $3^{\prime}-T_{1}$ to $\left.{ }^{131} I\right] 3,3^{\prime}-T_{2}$ increased progressively thereafter. In the incubations with $\left.{ }^{125} \mathrm{I}\right] \mathrm{T}_{4}$, using hypothyroid tissue, substantial quantities of $\left[{ }^{125} \mathrm{I}\right] \mathrm{T}_{3}$ and $\left.{ }^{125} \mathrm{I}\right] \mathrm{r} \mathrm{T}_{3}$ appeared at $30 \mathrm{~min}$, when there was barely detectable [125I] $3,3^{\prime}-T_{2}$. In the latter incubations, the ratios of $\left[{ }^{125} I\right]-$ $3,3^{\prime}-\mathrm{T}_{2}$ to both [ $\left.{ }^{125} \mathrm{I}\right]$ triiodothyronines increased progressively over the subsequent $90 \mathrm{~min}$.

Excess $\mathrm{I}^{-}$production. Under normal incubation conditions, $0-6 \%$ of the $\left[{ }^{125} \mathrm{I}\right] \mathrm{T}_{4}$ and $0-2 \%$ of the $\left[{ }^{131} \mathrm{I}\right] \mathrm{T}_{3}$ was converted to excess $\mathrm{I}^{-}$(e.g., see Table I and Fig. 2). The following alterations in incubation conditions all increased excess $\mathrm{I}^{-}$production up to $40 \%$ of the added $\mathrm{T}_{4}$ and $10 \%$ of the added $\mathrm{T}_{3}: \mathrm{pH} 6.5$, decreased protein concentration (particularly in the high-speed pellet), decreased DTT concentration, and preheating to $100^{\circ} \mathrm{C}$ for $30 \mathrm{~min}$. All of these conditions caused greatly decreased net formation of iodothyronines, and formation of $\mathrm{I}^{-}$from $\mathrm{T}_{3}$ was never rapid enough to explain more than a small part of the excess $\mathrm{I}^{-}$from $\mathrm{T}_{4}$. When $\mathrm{I}^{-}$production was analyzed by BAA and TAA chromatography and by paper electrophoresis in incubation mixtures preheated to $100^{\circ} \mathrm{C}$, results from all three systems were comparable. In one dilution experiment and in one experiment with $100^{\circ} \mathrm{C}$ preheating, parallel incubations with [ $\left.{ }^{125} \mathrm{I}\right] \mathrm{T}_{4}$ plus $\left[{ }^{131} \mathrm{I}\right] \mathrm{T}_{3}$, and $\left[{ }^{125} \mathrm{I}\right] \mathrm{T}_{4}$ plus $\left[{ }^{131} \mathrm{I}\right] \mathrm{r} \mathrm{T}_{3}$ resulted in $\sim 10 \%$ of the $\mathrm{T}_{4}$ converted to excess $\mathrm{I}^{-}$, while simultaneous $\mathrm{I}^{-}$production via $\mathrm{T}_{3}$ and $\mathrm{rT}_{3}$ intermediates, taken together, could account for $<1 \%$ of the added $T_{4}$.

Products of $\mathrm{T}_{4}$ and $\mathrm{T}_{3}$ degradation in homogenates of cerebral cortex from hypothyroid, euthyroid, and hy- 
TABLE I

Products of $T_{4}$ and $T_{3}$ Metabolism in Homogenates of Cerebral Cortex and Cerebellum of Normal and Hypothyroid Rats

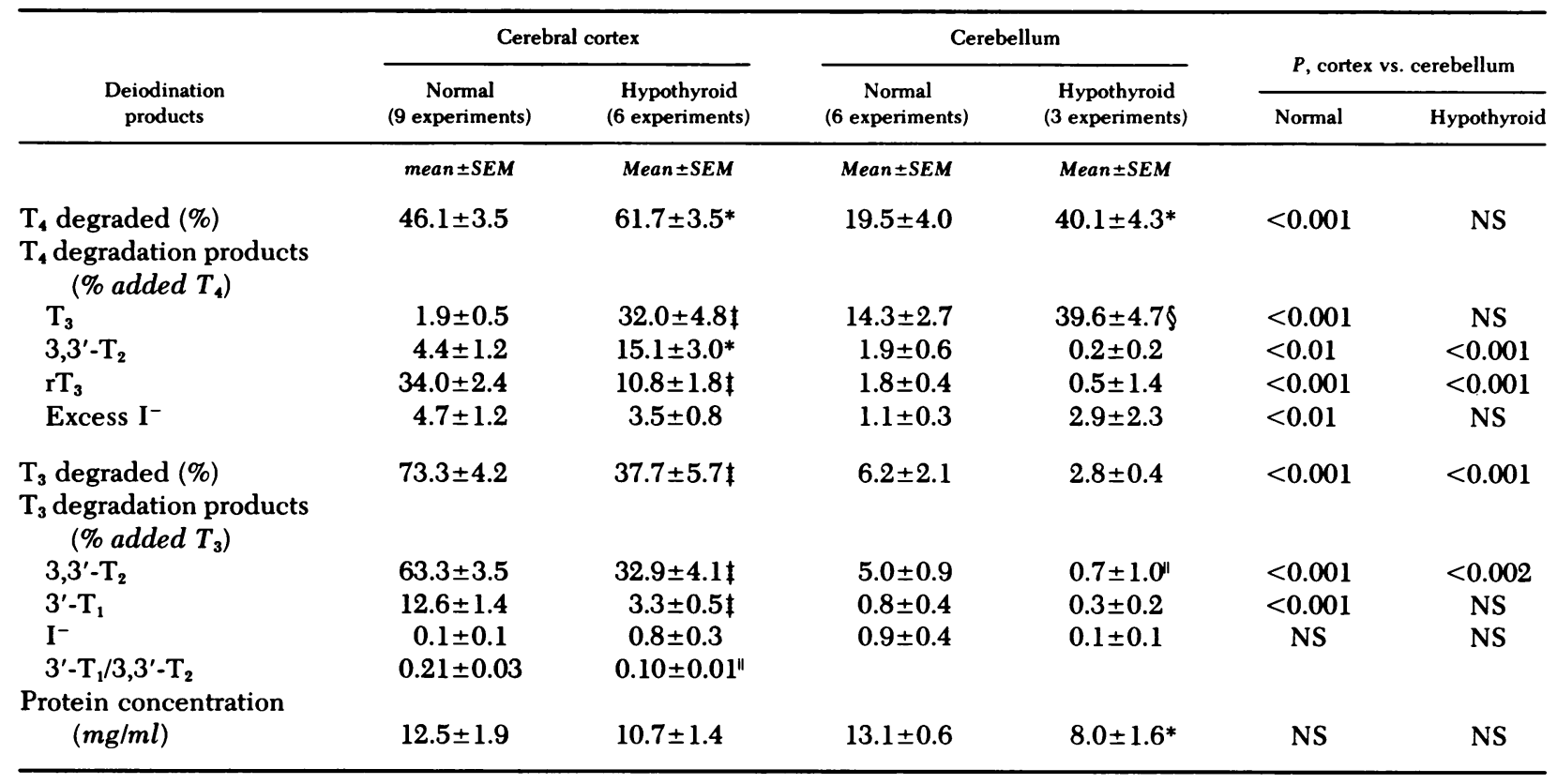

In each experiment, pooled homogenates from cerebral cortex or cerebellum of three rats were incubated in triplicate for $2 \mathrm{~h}$ at $37^{\circ} \mathrm{C}$ with $0.2-1.0 \mathrm{nM}\left[{ }^{125} \mathrm{I}\right] \mathrm{T}_{4}, 0.1-0.3 \mathrm{nM}\left[{ }^{131} \mathrm{I}\right] \mathrm{T}_{3}$, and $100 \mathrm{mM}$ DTT. Values are means of individual experimental means. Comparisons between normal and hypothyroid tissue were made by the unpaired $t$ test. Comparisons between cerebellum and cortex were made by two-way analysis of variance since, in each experiment with cerebellar tissue, values for cerebral cortical tissue from the same rats were available.

$* P<0.02$ vs. normal tissue from same region.

$\neq P<0.001$.

$\S P<0.005$.

" $P<0.05$.

perthyroid rats. In early experiments, using homogenates of cerebral cortex from normal rats, net production of small quantities of $\left[{ }^{125} \mathrm{I}\right] \mathrm{T}_{3}$ from $\left.{ }^{[125} \mathrm{I}\right] \mathrm{T}_{4}$ was observed. Because we were interested most in $T_{3}$ production, we sought a system in which it was more readily studied. Alterations in thyroid status were potentially useful, in view of their effects of pituitary and hepatic $T_{4} 5^{\prime}$-deiodination $(20,23,24)$. Because differences in endogenous $\mathrm{T}_{4}$ could alter the extent of $\mathrm{T}_{4}$ degradation in homogenates, incubations were carried out in the presence and absence of $100 \mathrm{nM}\left[{ }^{127} \mathrm{I}\right] \mathrm{T}_{4}$, a concentration much higher than any conceivably due to endogenous $\mathrm{T}_{4}$.

Results obtained using cerebral cortical homogenates from normal, hyperthyroid, and hypothyroid rats are shown in Fig. 2. The protein concentrations of the incubation mixtures (mean $\pm \mathrm{SD}$ ) were $10.3 \pm 0.8,10.5 \pm 0.2$, and $9.7 \pm 0.3 \mathrm{mg} / \mathrm{ml}$ in the euthyroid, hyperthyroid, and hypothyroid groups, respectively. In homogenates of cerebral cortex from normal and hyperthyroid rats (Fig. 2, center and right) the major $\left[{ }^{125} \mathrm{I}\right] \mathrm{T}_{4}$ degradation product was $\left[{ }^{125} \mathrm{I}\right] \mathrm{rT}_{3}$. There were also small quantities of $\left[{ }^{125} I\right] T_{3},\left[{ }^{125} I\right] 3,3^{\prime}-T_{2}$, and excess ${ }^{125} I^{-}$. In incubation mixtures from normal and hyperthyroid rats the estimated upper limit for production of both $3^{\prime}, 5^{\prime}-\mathrm{T}_{2}$ and $3^{\prime}-\mathrm{T}_{1}$ was $2.5 \%$ of the added $\mathrm{T}_{4}$ in $2 \mathrm{~h}$. In the incubations of normal and hyperthyroid cerebral cortex, the only significant effect of increasing the $\mathrm{T}_{4}$ concentration from 0.2 to $100 \mathrm{nM}$ was to decrease the total degradation of $\mathrm{T}_{4}$ in the normal group from $33.2 \pm 7.3$ to 27.1 $\pm 6.8 \%$ ( $P<0.05$ by paired $t$ test).

In homogenates of cerebral cortex from hypothyroid rats (Fig. 2, left), substantial quantities of $\left.{ }^{125} \mathrm{I}\right] \mathrm{T}_{3}$ and smaller quantities of $\left[{ }^{125} I\right] 3,3^{\prime}-T_{2}$ and $\left[{ }^{125} I\right] \mathrm{r}_{3}$ were produced from $\left.{ }^{[25} I\right] \mathrm{T}_{4}$. When the $\mathrm{T}_{4}$ concentration was increased from 0.2 to $100 \mathrm{nM}$, the fractional degradation of $\mathrm{T}_{4}$ decreased from $48.8 \pm 6.3$ to $28.8 \pm 6.4 \%(P<0.001)$, largely due to a decrease in $\mathrm{T}_{3}$ production from 30.0 to $15.3 \%$ of the added $T_{4}(P<0.05)$. Percent conversion of $T_{4}$ to the other products was not significantly different at the two $T_{4}$ concentrations. The greater fractional $T_{4}$ to $T_{3}$ conversion in the hypothyroid preparation with $100 \mathrm{nM} \mathrm{T}_{4}$ than in the other homogenates with only tracer $T_{4}$ shows that $T_{3}$ production in cerebral cortical homogenates from normal and hyperthyroid rats was not obscured by endogenous $T_{4}$. 


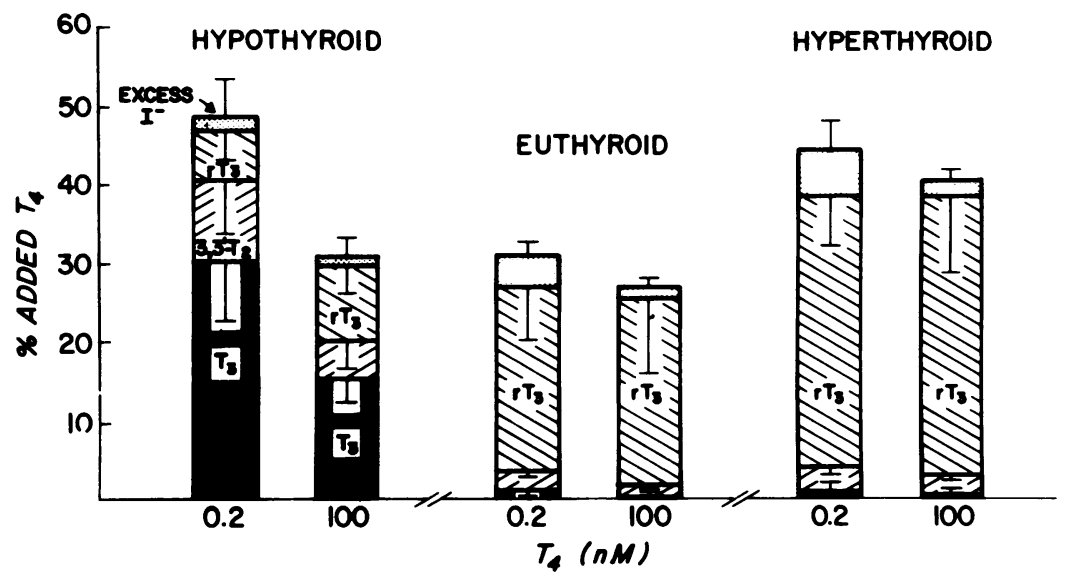

FIGURE 2 Effect of thyroid status on deiodination of $\left[{ }^{125} \mathrm{I}\right] \mathrm{T}_{4}$ in cerebral cortical homogenates. In this experiment tissue from each rat was homogenized and incubated separately. Three intact rats received $10 \mu \mathrm{g} \mathrm{T}_{4} / 100 \mathrm{~g}$ body wt. s.c. daily $\times 5$ to render them hyperthyroid, while three intact and three thyroidectomized rats received the $T_{4}$ vehicle in the same schedule. All the rats were sacrificed at the same time and the incubations (one tube per rat) were performed simultaneously. Incubations were performed at $37^{\circ} \mathrm{C}$ for $2 \mathrm{~h}$ with $0.2 \mathrm{nM}\left[{ }^{125} \mathrm{I}\right] \mathrm{T}_{4}$, with and without $100 \mathrm{nM}\left[{ }^{127} \mathrm{I}\right] \mathrm{T}_{4}, 0.1 \mathrm{nM}\left[{ }^{131} \mathrm{I}\right] \mathrm{T}_{3}$, and $100 \mathrm{mM}$ DTT. Vertical lines show $1 \mathrm{SD} . \mathrm{\square}, \mathrm{T}_{3} ; घ, 3,3^{\prime}-\mathrm{T}_{2}$; 四, $\mathrm{rT}_{3}$; and $\boldsymbol{x}$, excess $\mathrm{I}^{-}$.

The rates of $T_{3}$ degradation, $3,3^{\prime}-T_{2}$ production, and $3^{\prime}-T_{1}$ production were least in the homogenates from hypothyroid rats, greater in homogenates from euthyroid rats, and greatest in homogenates from hyperthyroid rats. The rates in the hyperthyroid group were two- to fourfold greater than those in the hypothyroid group. There was no effect on $\left[{ }^{131} \mathrm{I}\right] \mathrm{T}_{3}$ metabolism of increasing the $T_{4}$ concentration from 0.2 to $100 \mathrm{nM}$.

Inasmuch as there was clearly no enhancement of $\mathrm{T}_{3}$ production in cerebral cortical homogenates of hyperthyroid rats, either normal or hypothyroid rats were used in subsequent experiments. The combined results of several experiments are shown in Table $I$. At tracer $T_{4}$ and $T_{3}$ concentrations, mean net production of $\mathrm{T}_{3}$ from $\mathrm{T}_{4}$ in cerebral cortical homogenates from normal rats was $1.9 \pm 0.5 \%$ of added $\mathrm{T}_{4}$, a low but significant rate. In cerebral cortical homogenates from hypothyroid rats, mean net $\mathrm{T}_{3}$ production was $32 \%$, much greater than in normals. Conversely, cerebral cortical homogenates from hypothyroid rats exhibited significantly less tyrosyl ring deiodination of $T_{4}$ and $T_{3}$ and, as judged by the difference in the [ $\left.{ }^{131} I\right] 3^{\prime}-T_{1} /$ [131I] $3,3^{\prime}-T_{2}$ ratios, less tyrosyl ring deiodination of $3,3^{\prime}-\mathrm{T}_{2}$ than the cerebral cortical homogenates from the euthyroid rats.

To clarify the sources of $\left.{ }^{125} I\right] 3,3^{\prime}-T_{2}$, we performed parallel incubations, using the same homogenates, with $\left[{ }^{125} \mathrm{I}\right] \mathrm{T}_{4}$ plus $\left[{ }^{131} \mathrm{I}\right] \mathrm{T}_{3}$, and with $\left[{ }^{125} \mathrm{I}\right] \mathrm{T}_{4}$ plus $\left[{ }^{131} \mathrm{I}\right] \mathrm{rT}_{3} .{ }^{2} \mathrm{In}$ cerebral cortical homogenates from both normal and hypothyroid rats, fractional conversion of $T_{3}$ to $3,3^{\prime}-T_{2}$ was greater than fractional conversion of $\mathrm{rT}_{3}$ to $3,3^{\prime}-\mathrm{T}_{2}$. Conversion of $\mathrm{rT}_{3}$ to $3,3^{\prime}-\mathrm{T}_{2}$ was greater in the ho- mogenates from hypothyroid rats than from normals. Given the differences in availability of $\left[{ }^{125} \mathrm{I}\right] \mathrm{T}_{3}$ and $\left[{ }^{125} \mathrm{I}\right]$ $\mathrm{rT}_{3}$ during incubations using cortex from normal and hypothyroid rats (Table I), it could be concluded that $\mathrm{T}_{3}$ served as the intermediate for much (in normals) or most (in hypothyroid rats) of the $3,3^{\prime}-\mathrm{T}_{2}$ produced from $\mathrm{T}_{4}$ in cerebral cortical homogenates. It was also clear, however, that $\mathrm{rT}_{3}$ was the intermediate for some $3,3^{\prime}-\mathrm{T}_{2}$ produced from $\mathrm{T}_{4}$. Addition of 1 or $2 \mu \mathrm{M}\left[{ }^{127} \mathrm{I}\right] \mathrm{T}_{3}$ inhibited $\left.{ }^{[131} \mathrm{I}\right] \mathrm{T}_{3}$ degradation to $<10 \%$ and increased the simultaneous net production of $\left[{ }^{125} \mathrm{I}\right] \mathrm{T}_{3}$ from $\left[{ }^{125} \mathrm{I}\right] \mathrm{T}_{4}$, without significantly changing the sum of net $\left[{ }^{125} \mathrm{I}\right] \mathrm{T}_{3}$ plus net $\left[{ }^{125} I\right] 3,3^{\prime}-T_{2}$ production.

In view of the foregoing results using $\left.{ }^{\left[{ }^{31}\right.} \mathrm{I}\right] \mathrm{rT}_{3}$ and high concentrations of $\left.{ }^{[127} \mathrm{I}\right] \mathrm{T}_{3}$, it appeared that total $\mathrm{T}_{3}$ production rates in cerebral cortical homogenates from hypothyroid rats could be approximated well as the sum of net $T_{3}$ and net $3,3^{\prime}-T_{2}$ production. In two experiments using $100 \mathrm{nM}$ initial $\mathrm{T}_{4}$ concentration (one shown in Fig. 2), total $T_{3}$ production rates were 8.1 and $17.5 \mathrm{fmol} \mathrm{T}_{3} / \mathrm{min}$ per $\mathrm{mg}$ homogenate protein. In these experiments, incubations with $1,000 \mathrm{nM} \mathrm{T}_{4}$ were included: fractional $T_{4}$ to $T_{3}$ conversion was very low, and changed between 100 and $1,000 \mathrm{nM} \mathrm{T}$ approximately in inverse proportion to the concentration. Therefore, $100 \mathrm{nM} \mathrm{T}_{4}$ was probably greater than the apparent $K_{\mathrm{m}}$ for $T_{4}$ in this reaction, and the measured $T_{3}$ production rates at $100 \mathrm{nM} \mathrm{T}_{4}$ approximated maximum reaction rates.

Iodothyronine deiodinating activities in cerebellar homogenates. The mean $\mathrm{T}_{4}$ to $\mathrm{T}_{3}$ conversion rate in the cerebellar homogenates from normal rats was con- 
siderably greater than that in cerebral cortical homogenates from the normal rats (Table $I$ ). The mean $T_{4}$ to $T_{3}$ conversion rate in cerebellar homogenates from hypothyroid rats was the same as that in cerebral cortical homogenates from the hypothyroid rats, and much greater than in the cerebellar homogenates from the normal rats. In dramatic contrast, there was little or no $\mathrm{T}_{4}$ to $\mathrm{rT}_{3}$ conversion in cerebellar homogenates from normal or hypothyroid rats. $T_{3}$ to $3,3^{\prime}-T_{2}$ conversion was present in cerebellar homogenates from normal rats but was much slower than in cerebral cortical homogenates. $T_{3}$ to $3,3^{\prime}-T_{2}$ conversion was not detectable in cerebellar homogenates from hypothyroid rats.

Thiol dependence of deiodination reactions. Whole homogenates of cerebral cortex from normal and hypothyroid rats were incubated with tracer $T_{4}$ and $T_{3}$ in the presence of $0-100 \mathrm{mM}$ DTT. There was no detectable degradation of $T_{4}$ or $T_{3}$ in the absence of DTT. In the hypothyroid preparations (Fig. 3), there was a progressive increase in percent conversion of $\left[{ }^{125} \mathrm{I}\right] \mathrm{T}_{4}$ to $\left[{ }^{125} \mathrm{I}\right] \mathrm{T}_{3}$ as the DTT concentration was increased up to $10 \mathrm{mM}$ and no significant further change at 50 or $100 \mathrm{mM}$ DTT. In the same hypothyroid preparations, there was a progressive increase in conversion of $\left[{ }^{131} \mathrm{I}\right] \mathrm{T}_{3}$ to $\left[{ }^{131} \mathrm{I}\right] 3,3^{\prime}-\mathrm{T}_{2}$ up to $100 \mathrm{mM}$ DTT and an increase in net accumulation of $\left[{ }^{125} \mathrm{I}\right] 3,3^{\prime}-\mathrm{T}_{2}$. The low $3,3^{\prime}-\mathrm{T}_{2}$ production rates in this experiment did not allow precise definition of the DTT dose-response relationship. In the homogenates of cerebral cortex from normal rats (Fig. 4), the rate of $\mathrm{T}_{4}$ to $\mathrm{rT}_{3}$ conversion and the rate of $T_{3}$ to $3,3^{\prime}-T_{2}$ conversion increased progressively as the DTT concentration was varied from 0 to
$50 \mathrm{mM}$, with no significant differences between 50 and $100 \mathrm{mM}$ DTT. The production of $3^{\prime}-\mathrm{T}_{1}$ from $\mathrm{T}_{3}$ had a similar relationship to the DTT concentration. In normal rats, there was no significant $T_{4}$ to $T_{3}$ conversion in cerebellar homogenates, and low rates of $T_{3}$ to $3,3^{\prime}-T_{2}$ conversion in cerebral cortical homogenates when $100 \mathrm{mM}$ GSH was used instead of DTT. $100 \mathrm{mM}$ GSH was slightly less effective than $1 \mathrm{mM}$ DTT in stimulating $T_{3}$ to $3,3^{\prime}-T_{2}$ conversion.

Subcellular distribution of deiodinating activities. In normal, hypothyroid, and hyperthyroid rats, the extent of conversion of $T_{4}$ to $T_{3}, T_{4}$ to $\mathrm{rT}_{3}$, and $T_{3}$ to $3,3^{\prime}-T_{2}$ was the same, or only slightly less, in the resuspended low- and high-speed pellets as in the whole homogenates. In the hypothyroid rats, the $\mathrm{T}_{4} 5^{\prime}$-deiodination rate per milligram protein was less in cytosol than in other fractions. In all three groups, the rate of $T_{4} 5$ deiodination per milligram protein was less in the highspeed supernate than in the high-speed pellet; this was probably true for 5-deiodination of $\mathrm{T}_{3}$ also, after accounting for the decrease in reaction rate as the substrate became largely depleted. Since the amount of the various products were similar in the washed highspeed pellet and in the whole homogenate in all three groups, differences in cytosol binding of $T_{4}$ clearly did not prevent the detection of $T_{3}$ production in the whole homogenates of cerebral cortex from normal and hyperthyroid rats.

The effects of dilution of the high-speed pellet was studied. ${ }^{2}$ In the high-speed pellet from hypothyroid rats, the rate of conversion of $T_{4}$ to $T_{3}$ had a reasonably linear, direct relationship to the amount of protein in the incubation tubes between 1.5 and $11.5 \mathrm{mg}$ protein/

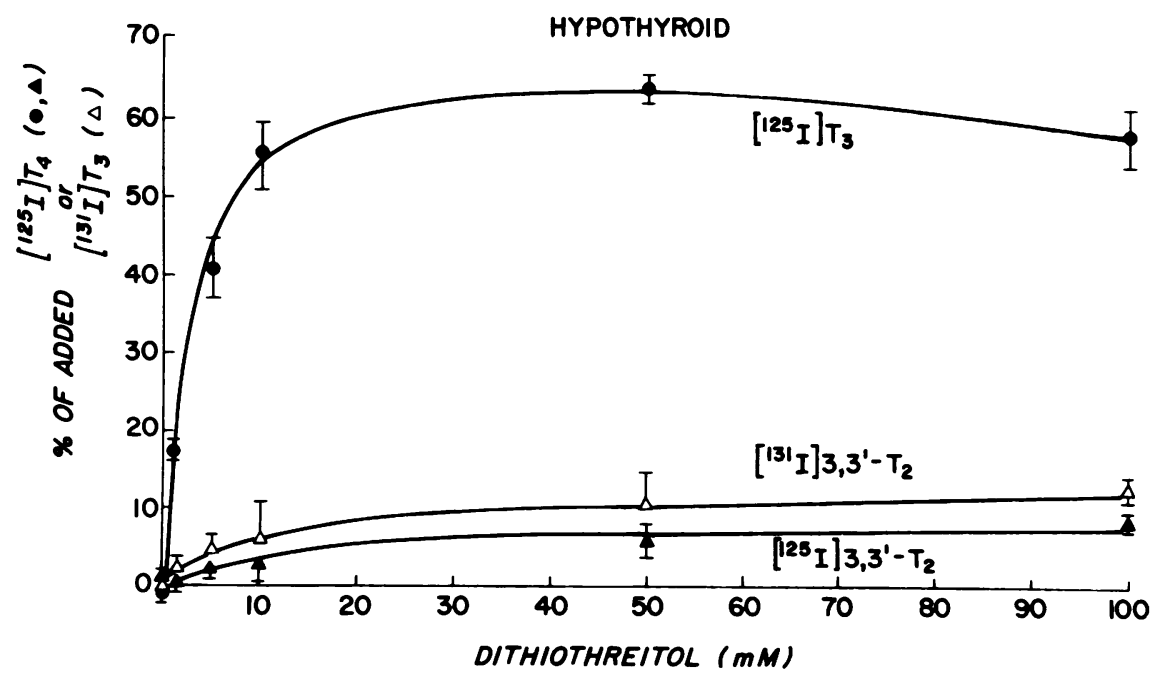

FIGURE 3 Dependence on DTT concentration of $\mathrm{T}_{4}$ and $\mathrm{T}_{3}$ deiodination in pooled cerebral cortical homogenates from three hypothyroid rats. Points represent mean $\pm S D$ of triplicate incubations with $0.4 \mathrm{nM}\left[{ }^{125} \mathrm{I}\right] \mathrm{T}_{4}$ and $0.2 \mathrm{nM}\left[{ }^{131} \mathrm{I}\right] \mathrm{T}_{3}$ at $37^{\circ} \mathrm{C}$ for $2 \mathrm{~h}$. Production of $\left[{ }^{125} \mathrm{I}\right] \mathrm{rT}_{3},\left[{ }^{131} \mathrm{I}\right]-$ $3^{\prime}-\mathrm{T}_{1}$, and excess ${ }^{125} \mathrm{I}^{-}$were at most $4 \%$ of added $\left[{ }^{125} \mathrm{I}\right] \mathrm{T}_{4}$ or $\left[{ }^{131} \mathrm{I}\right] \mathrm{T}_{3}$ at all DTT concentrations. 


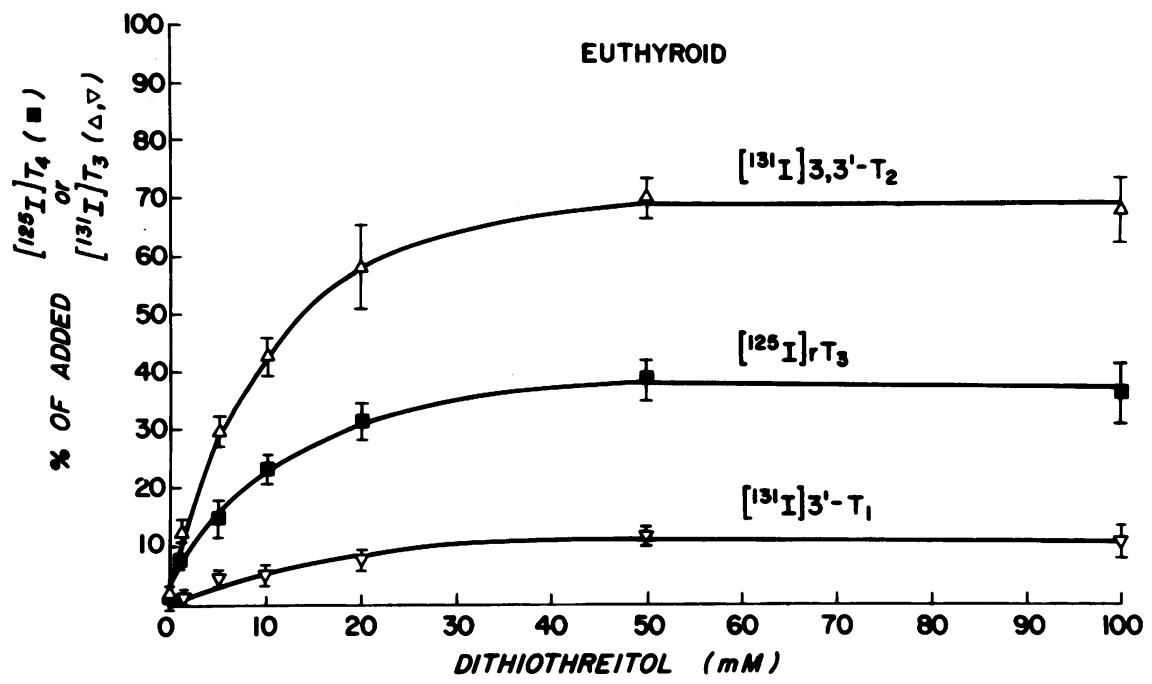

Figure 4 Dependence on DTT concentration of $T_{4}$ and $T_{3}$ deiodination in pooled cerebral cortical homogenates from three euthyroid rats. Points represent mean $\pm \mathrm{SD}$ of triplicate incubations with $0.5 \mathrm{nM}\left[{ }^{125} \mathrm{I}\right] \mathrm{T}_{4}$ and $0.3 \mathrm{nM}\left[{ }^{131} \mathrm{I}\right] \mathrm{T}_{3}$ at $37^{\circ} \mathrm{C}$ for $2 \mathrm{~h}$. Production of $\left[{ }^{125} \mathrm{I}\right] \mathrm{T}_{3}$ was $<2 \%$ and production of excess ${ }^{125} \mathrm{I}^{-}$was $<4 \%$ of added $\left[{ }^{125} \mathrm{I}\right] \mathrm{T}_{4}$ at all DTT concentrations.

$\mathrm{ml}$. When the high-speed pellet from normal rats was diluted from 8.8 to $1.1 \mathrm{mg} / \mathrm{ml}$, the percent conversion of $\mathrm{T}_{4}$ to $\mathrm{rT}_{3}$ decreased progressively, but the relationship was not linear above $4.4 \mathrm{mg}$ protein $/ \mathrm{ml}$.

Inhibition of phenolic and tyrosyl ring deiodination in cerebral cortical tissue by iodothyronines and iopanoic acid. Results are shown in Tables II and III. Both $\mathrm{rT}_{3}$ and iopanoic acid (Table II) caused dosedependent inhibition of $T_{4}$ to $T_{3}$ conversion. Increasing the $T_{4}$ concentration from 1 to $1,000 \mathrm{nM}$ also caused a progressive reduction in fractional $T_{4}$ to $T_{3}$ conversion (Table II). The extent of inhibition of fractional $T_{4}$ to $T_{3}$ conversion by the agents used in these two experiments may be compared, since total $T_{4}$ degradation in the incubations with $\mathrm{T}_{4}$ up to $1 \mathrm{nM}$ were quite similar $(47.6 \pm 3.2 \%$ in experiment 1 and $45.0 \pm 2.0 \%$ in experiment 2). The effect of adding $1,000 \mathrm{nM} \mathrm{T}_{3}$ to the high-speed pellet from hypothyroid rats was the same as in the whole homogenate experiments, i.e., no inhibition of total $T_{3}$ production. Thus, for the $T_{4}$ to $T_{3}$ conversion reaction in the high-speed pellet fraction, the order of inhibitory potency was $T_{4}>$ iopanoic acid $>\mathrm{rT}_{3} \gg \mathrm{T}_{3}$.

$\mathrm{T}_{3}$ at $1,000 \mathrm{nM}$ greatly reduced fractional conver-

TABLE II

Inhibition of $T_{4} 5^{\prime}$-Deiodination by Cerebral Cortical Tissue from Hypothyroid Rats in vitro

\begin{tabular}{|c|c|c|c|c|}
\hline & Inhibitor & $\begin{array}{c}\left.\left[{ }^{123}\right]\right] \mathrm{T}_{3} \\
\text { production }\end{array}$ & $\begin{array}{l}{\left[{ }^{125} I\right] 3,3^{\prime}-T_{2}} \\
\text { production }\end{array}$ & $\begin{aligned} & {\left[{ }^{125} I\right] \mathrm{T}_{3} } \\
+ & {\left[{ }^{125} I\right] 3,3^{\prime}-\mathrm{T}_{2} }\end{aligned}$ \\
\hline & $n M$ & & $\%$ added $T_{4} \pm$ & \\
\hline Experiment 1 & $\begin{array}{l}\text { None } \\
\mathrm{rT}_{3} 100 \\
\mathrm{rT}_{3} 1,000 \\
\text { Iopanoic acid } 300 \\
\text { Iopanoic acid } 1,000\end{array}$ & $\begin{array}{r}21.4 \pm 1.6 \\
13.2 \pm 1.4 \\
4.8 \pm 0.6 \\
8.4 \pm 0.4 \\
2.6 \pm 1.0\end{array}$ & $\begin{array}{l}8.0 \pm 2.0 \\
5.0 \pm 1.4 \\
1.0 \pm 0.9 \\
1.6 \pm 1.2 \\
1.2 \pm 1.6\end{array}$ & $\begin{array}{r}29.4 \pm 2.6 \\
18.2 \pm 2.0 \\
5.8 \pm 1.1 \\
10.0 \pm 1.3 \\
3.5 \pm 1.9\end{array}$ \\
\hline Experiment 2 & $\begin{array}{l}\text { None } \\
\mathrm{T}_{4} 10 \\
\mathrm{~T}_{4} 100 \\
\mathrm{~T}_{4} 1,000\end{array}$ & $\begin{array}{r}25.5 \pm 2.0 \\
16.8 \pm 1.7 \\
9.9 \pm 4.3 \\
0.0 \pm 0.6\end{array}$ & $\begin{array}{l}5.2 \pm 1.4 \\
3.8 \pm 0.3 \\
3.0 \pm 2.0 \\
0.9 \pm 0.9\end{array}$ & $\begin{array}{r}30.7 \pm 2.4 \\
20.6 \pm 1.7 \\
12.9 \pm 4.7 \\
0.9 \pm 1.1\end{array}$ \\
\hline
\end{tabular}

Incubations were carried out in triplicate at $37^{\circ} \mathrm{C}$ for $2 \mathrm{~h}$ in the presence of $0.4-1.0 \mathrm{nM}$ $\left[{ }^{125} \mathrm{I}\right] \mathrm{T}_{4}, 0.2 \mathrm{nM}\left[{ }^{131} \mathrm{I}\right] \mathrm{T}_{3}$, and $100 \mathrm{nM}$ DTT. In each experiment, cerebral cortical tissue from three hypothyroid rats was pooled and the high-speed pellet fraction was used in the incubations. 
TABLE III

Inhibition of $T_{4}$ and $T_{3}$ 5-Deiodination in the Cerebral Cortical

High-speed Pellet Fraction

\begin{tabular}{|c|c|c|c|}
\hline & Inhibitor & $\begin{array}{l}{\left[{ }^{125} \mathrm{I}\right] \mathrm{T}} \\
\text { converted to } \\
{\left[{ }^{[25} \mathrm{I}\right] \mathrm{rT}_{3}}\end{array}$ & $\begin{array}{l}{\left[{ }^{131} I\right] T_{3}} \\
\text { converted to } \\
{\left[{ }^{131} I\right] 3,3^{\prime}-T_{2}}\end{array}$ \\
\hline & $n M$ & $\%$ added $T_{4} \pm S D$ & $\%$ added $T_{3} \pm S D$ \\
\hline $\begin{array}{l}\text { Experiment } 1 \\
\text { (hypothyroid) }\end{array}$ & $\begin{array}{l}\text { None } \\
T_{4} 1,000 \\
T_{3} 1,000\end{array}$ & $\begin{array}{r}10.4 \pm 1.6 \\
4.4 \pm 2.9 \\
6.2 \pm 4.5\end{array}$ & $\begin{array}{r}15.3 \pm 1.4 \\
0.9 \pm 2.0 \\
-0.4 \pm 1.6\end{array}$ \\
\hline $\begin{array}{l}\text { Experiment } 2 \\
\text { (normal) }\end{array}$ & $\begin{array}{l}\text { None } \\
\mathrm{T}_{4} 100 \\
\mathrm{~T}_{4} 1,000 \\
\text { Iopanoic acid } 1,000 \\
\text { Iopanoic acid } 50,000\end{array}$ & $\begin{array}{r}27.6 \pm 3.2 \\
18.5 \pm 3.2 \\
7.9 \pm 4.7 \\
6.8 \pm 2.7 \\
0.7 \pm 2.8\end{array}$ & $\begin{array}{r}67.8 \pm 2.6 \\
37.9 \pm 4.2 \\
10.3 \pm 1.7 \\
17.0 \pm 4.9 \\
1.7 \pm 4.8\end{array}$ \\
\hline $\begin{array}{l}\text { Experiment } 3 \\
\text { (hypothyroid) }\end{array}$ & $\begin{array}{l}\text { None } \\
\mathrm{rT}_{3} 100 \\
\mathrm{rT}_{3} 1,000 \\
\text { Iopanoic acid } 300 \\
\text { Iopanoic acid } 1,000\end{array}$ & $\begin{array}{r}10.2 \pm 2.4 \\
10.4 \pm 2.0 \\
11.5 \pm 2.0 \\
2.6 \pm 3.0 \\
0.0 \pm 1.8\end{array}$ & $\begin{array}{r}28.9 \pm 2.6 \\
26.7 \pm 2.4 \\
24.1 \pm 1.9 \\
12.6 \pm 2.0 \\
3.4 \pm 1.3\end{array}$ \\
\hline
\end{tabular}

Tissue preparation and reaction conditions were as described in TABLE II.

sion of $\left[{ }^{131} I\right] T_{3}$ to $\left[{ }^{131} I\right] 3,3^{\prime}-T_{2}$ in the high-speed pellet from hypothyroid rats (Table III). The effect of $T_{3}$ on $\mathrm{T}_{4}$ to $\mathrm{rT}_{3}$ conversion in experiment 1 was indeterminate. $T_{4}$ was an effective inhibitor of fractional conversion of $\left[{ }^{125} \mathrm{I}\right] \mathrm{T}_{4}$ to $\left[{ }^{125} \mathrm{I}\right] \mathrm{r} \mathrm{T}_{3}$ and of $\left[{ }^{131} \mathrm{I}\right] \mathrm{T}_{3}$ to $\left[{ }^{131} \mathrm{I}\right] \mathrm{T}_{2}$ (Table III). $1 \mu \mathrm{M} \mathrm{T}_{4}$ was approximately as potent as $1 \mu \mathrm{M} \mathrm{T}_{3}$ in inhibiting fractional conversion of $\left[{ }^{131} \mathrm{I}\right] \mathrm{T}_{3}$ to $\left[{ }^{131} \mathrm{I}\right] 3,3^{\prime}-\mathrm{T}_{2}$. Iopanoic acid inhibited $\mathrm{T}_{4}$ to $\mathrm{rT}_{3}$ conversion and $\mathrm{T}_{3}$ to $3,3^{\prime} \mathrm{T}_{2}$ conversion (Table III). The potency of iopanoic acid in the inhibition of 5-deiodination of $T_{4}$ and $T_{3}$ was approximately equal to that of $\mathrm{T}_{4}$ in the high-speed pellet from normal rats (Table III). $\mathrm{rT}_{3}$ at 100- and 1,000-nM concentrations did not inhibit $T_{4}$ to $\mathrm{r}_{3}$ conversion or $\mathrm{T}_{3}$ to $3,3^{\prime}-\mathrm{T}_{2}$ conversion (Table III). From these data the order of inhibitory potency of these compounds for the 5deiodination reaction in the cerebral cortical highspeed pellet was $T_{3} \simeq T_{4} \simeq$ iopanoic acid $\gg \mathrm{rT}_{3}$.

\section{DISCUSSION}

The studies we report here demonstrate complex patterns of deiodinative iodothyronine metabolism in rat brain homogenates. It seems clear that rat brain possesses separate phenolic and tyrosyl ring deiodinases. For both of these enzymes, activity is heat labile and thiol dependent. The rates of the two types of reactions in cerebral cortical homogenates vary in opposite directions in hypothyroidism. The activities of these enzymes also vary independently in different regions of the brain. The relationship of our results to those of Tata et al. (18) is obscure, probably due to substantial methodological differences. It is not clear whether the compounds they identified as triac and tetrac, or the corresponding propionic acid analogues, could have been $3,3^{\prime}-\mathrm{T}_{2}$ and $\mathrm{rT}_{3}$. Certainly, no alterations in the alanine side chain of $T_{4}$ or $T_{3}$ were observed in the present studies.

The formation of excess $\mathrm{I}^{-}$from $\mathrm{T}_{4}$, particularly in homogenates preheated to $100^{\circ} \mathrm{C}$, raises the possibility that we have misinterpreted nonspecific processes $(30,31)$ as being enzymatic reactions. This seems most unlikely for several reasons. First, the processes that form identifiable iodothyronine products of $T_{4}$ and $T_{3}$ degradation always behaved as expected for enzymatic reactions. They showed dependence on $\mathrm{pH}$, temperature, and protein concentration, regional specificity within the brain, and dependence on the thyroid status of the animals. Second, we did not observe rapid deiodination of $T_{3}$ and $\mathrm{rT}_{3}$, the known degradation products of $T_{4}$, in preboiled homogenates. This result excluded sequential deiodination through those intermediates. Third, all of the manipulations that increased excess $\mathrm{I}^{-}$formation greatly reduced the net formation of all identifiable iodothyronine products. Although the nature of excess $\mathrm{I}^{-}$formation is unknown, it appeared to be largely unrelated to formation of iodothyronine products of $T_{4}$ degradation and may well be nonenzymatic.

The significance of $T_{4} 5$-deiodinase activity in the brain, with respect to the responses of the brain to circulating thyroid hormones, is not yet known. Crantz and Larsen (17) have shown that $T_{3}$ is produced from $\mathrm{T}_{4}$ within the cerebral cortex and the cerebellum of 
normal rats in vivo. They have recently reported (32) that $>70 \%$ of the endogenous nuclear $T_{3}$ in these brain regions is produced locally. This means that local $T_{3}$ production, compared with $\mathrm{T}_{3}$ transport from the blood, is at least as important in determining occupancy of nuclear $\mathrm{T}_{3}$ binding sites in the cerebral cortex and cerebellum as in the anterior pituitary gland $(33,34)$. Local $T_{4}$ to $T_{3}$ conversion provides a much lower fraction of nuclear $T_{3}$ in other tissues (33-35). Inhibition by iopanoic acid of $T_{4} 5^{\prime}$-deiodination within the anterior pituitary gland prevents physiological doses of $\mathrm{T}_{4}$ from suppressing TSH release in hypothyroid rats in vivo (35). Iopanoic acid inhibits local $T_{4}$ to $T_{3}$ conversion in vivo in the rat cerebral cortex and cerebellum (17), just as it does in pituitary (20) and brain homogenates. Hypothyroidism increases local $T_{4}$ to $T_{3}$ conversion in anterior pituitary fragments $(22)$ and probably in the anterior pituitary in vivo $(36,37)$. Parallel increases in in vivo $T_{4} 5^{\prime}$-deiodinase activity are readily measured in anterior pituitary and brain homogenates in hypothyroidism. These similarities lead us to anticipate that brain $\mathrm{T}_{4} 5^{\prime}$-deiodinase, the properties of which we are beginning to define in vitro, will prove to be necessary for the expression of some of the effects of blood $T_{4}$ on the brain.

The estimated maximal $T_{3}$ production rates in cerebral cortical homogenates from hypothyroid rats, 8.1-17.5 fmol $\mathrm{T}_{3} / \mathrm{min}$ per $\mathrm{mg}$ protein, are higher than the $T_{4}$ to $T_{3}$ conversion rates we previously measured in cerebral cortical homogenates from normal rats, $\sim 1 \mathrm{fmol} \mathrm{T}_{3} / \mathrm{min}$ per $\mathrm{mg}$ protein. In both normal and hypothyroid rats, maximum $T_{4}$ to $T_{3}$ conversion rates in anterior pituitary homogenates are 40-80 times greater than in cerebral cortical homogenates (20). We have speculated that the increased anterior pituitary $T_{4}$ 5 '-deiodinase activity in hypothyroidism could be caused by increased numbers of thyrotrophs (20). This explanation is obviously inapplicable to brain tissue. It seems more likely, therefore, that metabolic factors are in operation in the brain and the pituitary, e.g., an increased synthesis rate or a decreased turnover rate of the enzyme molecule.

$T_{4} 5^{\prime}$-deiodinase activity is also present in rat liver and kidney $(19,21,38-42)$. The 5 '-deiodinase enzymes in liver and kidney are very similar to one another and may well be the same $(19,42)$. Rat liver and kidney $\mathrm{T}_{4} 5^{\prime}$-deiodinases share several properties with rat brain and pituitary $\mathrm{T}_{4} 5^{\prime}$-deiodinases: inhibition by iopanoic acid and $\mathrm{rT}_{3}$, and lack of apparent interaction with $T_{3}(19,20,42,43)$. In these tissues, $T_{4} 5^{\prime}$-deiodinase is particulate, and cytosol has very little activity $(24,38-44)$. In at least one important respect, brain and pituitary $T_{4} 5^{\prime}$-deiodinase differ from the liver and kidney enzymes: in hypothyroidism, reaction rates in brain and pituitary homogenates are supernormal $(20,22)$, while reaction rates in liver and kidney homog- enates are subnormal $(23,45-48)$. Further purification will be required to establish the identity or difference between the $T_{4} 5^{\prime}$-deiodinase enzymes from these different organs.

Enzymatic tyrosyl ring deiodination of $T_{4}$ and $T_{3}$ has been identified in vitro in rat liver and kidney homogenates and in monkey hepatocarcinoma cells (49-55). Hepatic $\mathrm{T}_{4}$ to $\mathrm{rT}_{3}$ conversion is thiol dependent and heat labile $(50,52)$, and activity is found in particulate fractions as well as in cytosol $(50,54)$. These characteristics are similar to those that we find for brain iodothyronine 5-deiodinase. The finding of such substantial iodothyronine 5-deiodinase activity in brain tissue was unexpected, and its significance, if any, is unknown. Our data suggest that $\mathrm{rT}_{3}$ and the other $\mathrm{T}_{4}$ metabolite (very likely $3,3^{\prime}-\mathrm{T}_{2}$ ) found by Dratman and Crutchfield (14) in rat brain tissue after ${ }^{125} \mathrm{I}_{-} \mathrm{T}_{4}$ injection may well be produced within brain tissue in vivo. It is possible that the iodothyronine 5 -deiodinase participates in regulation of thyroid hormone effects by providing a mechanism for intracellular $\mathrm{T}_{3}$ disposal, inasmuch as $T_{4}$ and $T_{3}$ tyrosyl ring deiodination products produced endogenously have not yet been shown to exert hormonal effects.

From our studies, methodological recommendations for future in vitro studies of production of $\mathrm{T}_{4}, \mathrm{rT}_{3}$, and other iodothyronines in brain tissue can be made. Thiol concentration needs to be carefully controlled. Degradation of reaction products needs to be evaluated along with production, because, at least for $T_{3}$, net increases in $T_{3}$ can seriously underestimate total $T_{3}$ production. It is desirable to adjust reaction conditions to minimize excess $\mathrm{I}^{-}$production or, at any rate, to take account of the process because it affects substrate concentrations during incubations. Certainly, production of $I^{-}$from $T_{4}$ can not be equated with $T_{3}$ production.

It is becoming increasingly clear that quantitatively and qualitatively distinct patterns of thyroid metabolism occur within various tissues. Even within the brain, the cerebral cortex and the cerebellum exhibit this diversity according to our studies. Clearer understanding of thyroid hormone action will follow from study of intracellular thyroid hormone metabolism. Accumulating evidence suggests that the circulating pool of $\mathrm{T}_{4}$ is a reservoir which is drawn upon to provide substrate for closely regulated, local $T_{3}$ production. This mechanism may allow tissues to provide themselves with $T_{3}$ according to their particular requirements for thyroid hormone effects.

\section{ACKNOWLEDGMENTS}

We thank Dr. Reed Larsen for many valuable discussions and Ms. Melissa Jones for expert manuscript preparation.

This paper was supported in part by National Institutes of Health grant AM05826, Biomedical Research Support grant S07 RR05489 from the Division of Research Resources, 
National Institutes of Health, and Research Career Development Award AM-00727-01.

\section{REFERENCES}

1. Rosman, N. P. 1972. The neuropathology of congenital hypothyroidism. In Human Development and the Thyroid Gland. J. B. Stanbury and R. L. Kroc, editors. Plenum Press, New York. 337-366.

2. Balázs, R. 1974. Influence of metabolic factors on brain development. Br. Med. Bull. 30: 126-134.

3. Brasel, J. A., and D. B. Boyd. 1975. Influence of thyroid hormone on fetal brain growth and development. In Perinatal Thyroid Physiology and Disease. D. A. Fisher and G. N. Burrow, editors. Raven Press, New York. 59-71.

4. Legrand, J. 1977. Morphologic and biochemical effects of hormones on the developing nervous system in mammals. In Brain, Fetal and Infant. S. R. Berenberg, editor. Martinus Nijhoff Medical Division, the Hague. 137-164.

5. Ruiz-Marcos, A., F. Sanchez-Toscano, F. Escobar Del Ray, and G. Morreale De Escobar. 1979. Severe hypothyroidism and the maturation of the rat cerebral cortex. Brain Res. 162: 315-329.

6. Davis, P. J., J. R. Rappeport, J. H. Lutz, and R. I. Gregerman. 1971. Three thyrotoxic criminals. Ann. Intern. Med. 74: 743-745.

7. Asher, R. 1949. Myxoedematous madness. Br. Med. J. 2: 555-562.

8. Oppenheimer, J. H., H. L. Schwartz, and M. I. Surks. 1974. Tissue differences in the concentration of triiodothyronine nuclear binding sites in the rat: liver, kidney, pituitary, heart, brain, spleen and testis. Endocrinology. 95: 897-903.

9. Schwartz, H. L., and J. H. Oppenheimer. 1978. Nuclear triiodothyronine receptor sites in brain: probable identity with hepatic receptors and regional distribution. Endocrinology. 103: 267-273.

10. Schwartz, H. L., and J. H. Oppenheimer. 1978. Ontogenesis of 3,5,3'-triiodothyronine receptors in neonatal rat brain: dissociation between receptor concentration and stimulation of oxygen consumption by 3,5,3'-triiodothyronine. Endocrinology. 103: 943-948.

11. Valcana, T., and P. S. Timiras. 1978. Nuclear triiodothyronine receptors in the developing rat brain. Mol. Cell. Endocr. 11: 31-41.

12. Dratman, M. B., F. L. Crutchfield, J. Axelrod, R. W. Colburn, and N. Thoa. 1966. Localization of triiodothyronine in nerve ending fractions of rat brain. Proc. Natl. Acad. Sci. U. S. A. 73: 941-944.

13. Dozin-Van Roye, B., and P. DeNayer. 1978. Triiodothyronine binding to brain cytosol receptors during maturation. FEBS (Fed. Eur. Biochem. Soc.) Lett. 96: 152-154.

14. Dratman, M. B., and F. L. Crutchfield. 1978. Synaptosomal ( $\left.{ }^{125} I\right)$ triiodothyronine after intravenous ( ${ }^{125} I$ )thyroxine. Am. J. Physiol. 235: E638-E647.

15. Vigouroux, E., J. Clos, and J. Legrand. 1979. Uptake and metabolism of exogenous and endogenous thyroxine in the brain of young rats. Horm. Metab. Res. 11: 228-232.

16. Obregon, M. J., F. Roelfsema, G. Morreale de Escobar, F. Escobar del Rey, and A. Querido. 1979. Exchange of triiodothyronine derived from thryoxine with circulating triiodothyronine as studied in the rat. Clin. Endocrinol. 10: 305-315.

17. Crantz, F. R., and P. R. Larsen. 1980. Rapid thyroxine to $3,5,3^{\prime}$-triiodothyronine conversion and nuclear $3,5,3^{\prime}$ triiodothyronine $\mathrm{T}_{3}$ binding in rat cerebral cortex and cerebellum. J. Clin. Invest. 65: 935-938.
18. Tata, J. R., J. E. Rall, and R. W. Rawson. 1957. Metabolism of L-thyroxine and L-3:5:3'-triiodothyronine by brain tissue preparations. Endocrinology. 60: 83-98.

19. Kaplan, M. M., and R. D. Utiger. 1978. Iodothyronine metabolism in rat liver homogenates. J. Clin. Invest. 61: 459-471.

20. Kaplan, M. M. 1980 . Thyroxine $5^{\prime}$-monodeiodination in rat anterior pituitary homogenates. Endocrinology. 106: 567-576.

21. Chopra, I. J. 1977. A study of extrathyroidal conversion of thyroxine $\left(\mathrm{T}_{4}\right)$ to 3,3 , 5 -triiodothyronine $\left(\mathrm{T}_{3}\right)$ in vitro. Endocrinology. 101: 453-463.

22. Cheron, R. G., M. M. Kaplan, P. R. Larsen. 1979. Physiological and pharmacological influences on thyroxine to $3,5,3^{\prime}$-triiodothyronine conversion and nuclear 3,5,3'triiodothyronine binding in rat anterior pituitary. J. Clin. Invest. 64: 1402-1414.

23. Kaplan, M. M., and R. D. Utiger. 1978. Iodothyronine metabolism in liver and kidney homogenates from hyperthyroid and hypothyroid rats. Endocrinology. 103: 156161.

24. Kaplan, M. M. 1979. Changes in the particulate subcellular component of hepatic thyroxine-5'-monodeiodinase in hyperthyroid and hypothyroid rats. Endocrinology. 105: 548-554.

25. Weeke, J., and H. Orskov. 1973. Synthesis of monolabeled 3,5,3'-triiodothyronine and thyroxine of maximum specific activity for radioimmunoassay. Scand. J. Clin. Lab. Invest. 32: 357-360.

26. Bellabarba, D., R. E. Peterson, and K. Sterling. 1968. An improved method for chromatography of iodothyronines. J. Clin. Endocrinol. Metab. 28: 305-307.

27. Roche, J., R. Michel, and S. Lissitzsky. 1964. Analysis of natural radioactive iodine compounds by chromatographic and electrophoretic methods. In Methods of Biochemical Analysis. D. Glick, editor. 12: 143-182.

28. Obregon, M. J., G. Morreale de Escobar, and F. Escobar del Rey. 1978. Concentrations of triiodo-L-thyronine in the plasma and tissues of normal rats, as determined by radioimmunoassay: comparison with results obtained by an isotopic equilibrium technique. Endocrinology. 103: 2145-2153.

29. Lowry, O. H., N. J. Rosebrough, A. L. Farr, and R. J. Randall. 1951. Protein measurement with the Folin phenol reagent. J. Biol. Chem. 193: 265-275.

30. Morreale de Escobar, G., F. Escobar del Rey, and P. L. Rodriguez. 1962. Activation by inert proteins of the flavin-induced photodependent deiodination of thyroxine. J. Biol. Chem. 237: 2041-2043.

31. Kobayashi, I., T. Yamada, and K. Shichijo. 1966. Nonenzymatic deiodination of thyroxine in vitro. Metab. Clin. Exp. 15: 1140-1148.

32. Crantz, F. R., and P. R. Larsen. 1980. Contribution of local thyroxine to $3,5,3^{\prime}$-triiodothyronine $\left(T_{3}\right)$ conversion to nuclear $T_{3}$ in rat cerebral cortex and cerebellum. Clin. Res. 28: 478A. (Abstr.)

33. Silva, J. E., and P. R. Larsen. 1978. Contributions of plasma triiodothyronine and local thyroxine monodeiodination to triiodothyronine to nuclear triiodothyronine receptor saturation in pituitary, liver, and kidney of hypothyroid rats. Further evidence relating saturation of pituitary nuclear triiodothyronine receptors and the acute inhibition of thyroid-stimulating hormone release. J. Clin. Invest. 61: 1247-1259.

34. Silva, J. E., T. E. Dick, and P. R. Larsen. 1978. The contribution of local tissue thyroxine monodeiodination to the nuclear 3,5,3'-triiodothyronine in pituitary, liver, 
and kidney of euthyroid rats. Endocrinology. 103: 1196-1207.

35. Larsen, P. R., T. E. Dick, B. P. Markovitz, M. M. Kaplan, and T. G. Gard. 1979. Inhibition of intrapituitary thyroxine to $3,5,3^{\prime}$-triiodothyronine conversion prevents the acute suppression of thyrotropin release by thyroxine in hypothyroid rats. J. Clin. Invest. 64: 117-128.

36. Reichlin, S., E. M. Volpert, and S. C. Werner. 1966. Hypothalamic influence on thyroxine monodeiodination by rat anterior pituitary gland. Endocrinology. 78: 302-306.

37. Grinberg, R., E. M. Volpert, and S. C. Werner. 1963. In vivo deiodination of labelled L-thyroxine to $\mathrm{L}-3,5,3$ ' triiodothyronine in mouse and human pituitaries. $J$. Clin. Endocrinol. Metab. 23: 140-142.

38. Hesch, R. D., G. Brunner, and H. D. Söling. 1975. Conversion of thyroxine $\left(T_{4}\right)$ and triiodothyronine $\left(T_{3}\right)$ and the subcellular localization of the converting enzyme. Clin. Chim. Acta. 59: 209-213.

39. Visser, T. J., I. Van der Does-Tobe, R. Docter, and G. Hennemann. 1976. Subcellular localization of a rat liver enzyme converting thyroxine to triiodothyronine and possible involvement of essential thiol groups. Biochem. J. 157: 479-493.

40. Chiraseveenuprapund, P., U. Buergi, A. Goswami, and I. N. Rosenberg. 1978. Conversion of L-thyroxine to triiodothyronine in rat kidney homogenate. Endocrinology. 102: 612-622.

41. Leonard, J. L., and I. N. Rosenberg. 1978. Subcellular distribution of thyroxine 5 -deiodinase in the rat kidney: a plasma membrane location. Endocrinology. 103: 274280.

42. Kaplan, M. M., J. B. Tatro, R. Breitbart, and P. R. Larsen. 1979. Comparison of thyroxine and 3,3,5'-triiodothyronine metabolism in rat kidney and liver homogenates. Metab. Clin. Exp. 28: 1139-1146.

43. Kaplan, M. M., and J. B. Tatro. 1980. Subcellular localization, solubilization and substrate specificity of rat pituitary thyroxine 5'-deiodinase. Program of the 62nd Annual Meeting of the Endocrine Society. 150. (Abstr.).

44. Maciel, R. M. B., Y. Ozawa, and I. J. Chopra. 1979. Subcellular localization of thyroxine and reverse triiodothyronine outer ring monodeiodinating activities. Endocrinology. 104: 365-371.
45. Grussendorf, M., and M. Hüfner. 1977. Induction of the thyroxine $\left(\mathrm{T}_{4}\right)$ to triiodothyronine $\left(\mathrm{T}_{3}\right)$ converting enzyme in rat liver by thyroid hormone analogs. Clin. Chim. Acta. 80: 61-66.

46. Balsam, A., F. Sexton, and S. H. Ingbar. 1978. The effect of thyroidectomy hypophysectomy and hormone replacement on the formation of triiodothyronine from thyroxine in rat liver and kidney. Endocrinology. 103: 1759-1767.

47. Harris, A. R. C., S. L. Fang, A. G. Vagenakis, and L. E. Braverman. 1978. Effect of starvation, nutriment replacement, and hypothyroidism on in vitro hepatic $T_{4}$ to $T_{3}$ conversion in the rat. Metab. Clin. Exp. 27: 1680-1690.

48. Larson, F. D., K. Tomita, and E. C. Albright. 1955. Deiodination of thyroxine to triiodothyronine by kidney slices of rats with varying thyroid function. Endocrinology. 57: 338-344.

49. Chopra, I. J., S. Y. Wu, Y. Nakamura, and D. H. Solomon. 1978. Monodeiodination of 3,5,3'-triiodothyronine and $3,3^{\prime}, 5^{\prime}$-triiodothyronine to 3,3'-diiodothyronine in vitro. Endocrinology. 102: 1099-1106.

50. Cavalieri, R. R., L. A. Gavin, F. Bui, and M. Hammond. 1977. Conversion of thyroxine to $3,3^{\prime}, 5^{\prime}$-triiodothyronine (reverse- $\mathrm{T}_{3}$ ) by a soluble enzyme system of rat liver. Biochem. Biophys. Res. Commun. 79: 897-902.

51. Gavin, L. A., F. A. McMahon, and R. R. Cavlieri. 1978. Thyroxine deiodination in rat liver and kidney: the differential effects of glucose refeeding. Program of the 54th Meeting of the American Thyroid Association, T6 (Abstr.).

52. Visser, T. J., D. Fekkes, R. Docter, and G. Hennemann. 1978. Sequential deiodination of thyroxine in rat liver homogenate. Biochem. J. 174: 221-229.

53. Hüfner, M., and M. Grussendorf. 1978. Investigations on the deiodination of thyroxine $\left(\mathrm{T}_{4}\right)$ to $3,3^{\prime}$-diiodothyronine $\left(3,3^{\prime}-\mathrm{T}_{2}\right)$ in rat liver homogenate. Clin. Chim. Acta. 85: 243-251.

54. Höffken, B., R. Ködding, A. VonZur Mühlen, T. Hehrmann, H. Jüppner, and R. D. Hesch. 1978. Regulation of thyroid hormone metabolism in rat liver fractions. Biochim. Biophys. Acta. 539: 114-124.

55. Sorimachi, K., and J. Robbins. 1977. Metabolism of thyroid hormones by cultured monkey hepatocarcinoma cells. Nonphenolic ring deiodination and sulfation. J. Biol. Chem. 252: 4458-4463. 